\title{
含 $\mathrm{Cr}$ 低合金鋼粉焼結鍛造材の機械的性質に
}

\section{及ぼす燒結条件の影響*}

\author{
鰐 川 周 治**, 武田徹**
}

Shuji Wanikawa and Tohru Takeda: The Effect of Sintering Condition on the Characteristic of Sinter-Forged Cr Bearing Low Alloy Steel.

In order to improve mechanical properties of sinter-forged $\mathrm{Cr}$ bearing low alloy steel, effects of primary sintering of preforms and secondary sintering after forging on mechanical properties were examined for spherical powder having the porous surface layer (CP) and conventional P/M steel powder of under 100 mesh size (FP). Results were summarized as follow:

1) Oxygen contents of $\mathrm{CP}$ and $\mathrm{FP}$ preforms were $50 \sim 60$ and 100 110 ppm respectively at the primary sintering temperature of $1250^{\circ} \mathrm{C}$ for $60 \mathrm{~min}$.

2) At the forging temperature of $1100^{\circ} \mathrm{C}$, the densities of both $\mathrm{CP}$ and $\mathrm{FP}$ sinter-forged steels were saturated at the forging pressure of $9 \mathrm{t} / \mathrm{cm}^{2}$.

3) The impact strength of CP sinter-forged steels was influenced by the mean free path of small pores, as well as oxygen content.

4) The secondary sintering plays an important role for increasing the impact strength of both CP and FP sinter-forged steels. With increasing sintering temperature, residual pores became spherical and impact strength increased. The impact strength of the sinter-forged steels sintered under the secondary sintering conditions (for cxample at $1250^{\circ} \mathrm{C}$ for over $30 \mathrm{~min}$ ) was located in the range of $13.5 \sim 15 \mathrm{~kg}-\mathrm{m}$ / $\mathrm{cm}^{2}$, while those of $\mathrm{CP}$ and $\mathrm{FP}$ sinter-forged steels (without the secondary sintering) were $8 \sim 9$ and 8.5 $\sim 9.5 \mathrm{~kg}-\mathrm{m} / \mathrm{cm}^{2}$ respectively.

5) Tensile strength and hardness of both $\mathrm{CP}$ and $\mathrm{FP}$ sinter-forged steels were not influenced by the sintering conditions.

(Received December 27, 1979)

\section{I 緒言}

著者らは先に粒子表首が多孔質で内部が密な形態を呈 L，压縮性と成形性とを同時汇満足する含 $\mathrm{Cr}$ 低合金銅 粉の製造法を開発し，粒子表層に $\mathrm{Cr}$ 主体の酸化物を含 むととを報告しだ、。

一般に焼結鍛造工程（密閉型鍛造ではてのような酸

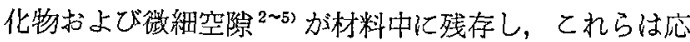
力下で切欠作用をして材料の勒性を低下させる．ての作 用はプレホーム焼結 (一次焼結) 時に酸化物を還元して 極力少なくするとと屯に，鏗造後，二次焼結して微細空 陌を球状化することによって㧕えることができると考え た.

本実験では上記の含 $\mathrm{Cr}$ 低合金銅粉 $(1 \% \mathrm{Cr}$ 鋼粉) ならびに同組成の-100 mesh 粉（粒子表層が多孔質で ない水噴霧粉）を用い，焼結条件が機械的性質にい加に 影響するか檢討を加えたので以下に報告する。

\section{II 実 験 方 法}

用いた原料粉の組成㧍よび特性を Table 1 亿示す。こ れら粉末に天然黒鉊（日本黒鈆製：AP）を炭素ぶどまり が0.4\%にになるように燒結条件によって CP の場合0.58 〜0.65\%の籍围（FP では $0.45 \sim 0.51 \%$ ）で配合量を調 整し，アルコール湿式混合した．との粉末を重量 43.5 $\pm 0.3 \mathrm{~g}$ 亿秤量 $し, 9 \times 53.5 \times 12.7 \sim 13.3 \mathrm{~mm} \mathrm{~K} 5 \mathrm{t} / \mathrm{cm}^{2}$ で成形後, $1100 \sim 1300^{\circ} \mathrm{C}, 10 \sim 60 \mathrm{~min}$, 脱炭を防止する ${ }^{6}$ ため $\mathrm{H}_{2} 4 \mathrm{l} / \mathrm{min}$ とプロパンガス $7 \mathrm{ml} / \mathrm{min}$ の漉合ガス気 流中で一次焼結した。なお，一次焼結後のプレホーム炭 素分析値は $0.4 \sim 0.42 \%$ の範团であった。

* 昭和52年 5 月本劦会春季大会儿て発表, 昭和 54 年12月27日 受理.

** 金属材料技術研究所，二153 東京都目黒区中目黒2-3-12

$\dagger \mathrm{H}_{2}$ 㥗高压ボンべより水素純化装置汇よって露点一 $70^{\circ} \mathrm{C}$ と し,プロパンガスは灲販の純度99.5\%のものである。これら の混合ガス括よび炏内の露点汕测定していない. 
Table 1 Properties of $1 \% \mathrm{Cr}$ steel powders.

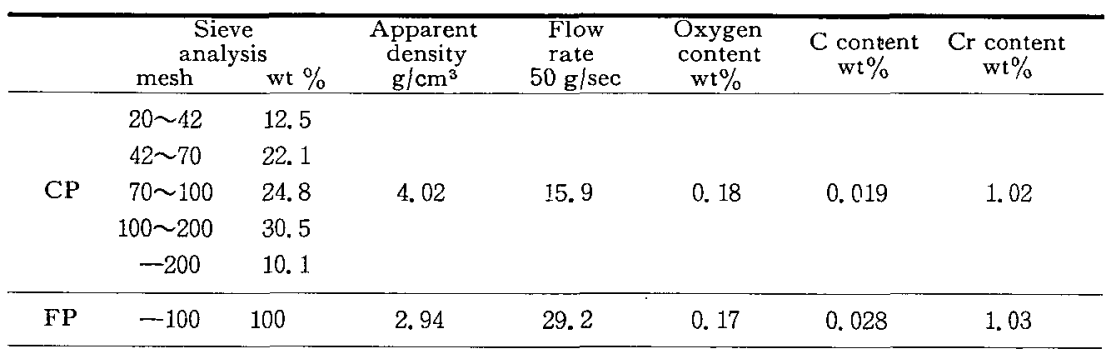

鈠造には 160 ton の小松製作所製マイプレスを用い， プレホームを $\mathrm{Ar}$ 雾囲気中で $900 \sim 1100^{\circ} \mathrm{C}$ に加熱, $4 \mathrm{~min}$ 間保持後，炉中より取り出し，6秒後 $10 \times 10 \sim 11 \times 55$ $\mathrm{mm}$ の形状に $5 \sim 12 \mathrm{t} / \mathrm{cm}^{2}$ で型鍜造（金型は特に昇温せ ず）し油冷した．鍛造時の潤滑にはコロイダルグラファ イト（日本黒鉛製：オイルハイト）を適用した。

鍛造した陚料を一次焼結 と同じ雲囲気中で 1000 ～ $1300^{\circ} \mathrm{C}, 10 \sim 60 \mathrm{~min}$ 二次烓結した. なお二次焼結の効果 を比較するため一部試料を $850^{\circ} \mathrm{C}, 30 \mathrm{~min}$ 焼ならしした。 二次焼結ならびに焼ならし試料を Fig. 1 のように JIS 規格2202に準じ，シャルピー4 号試験片に R $0.25 \mathrm{~mm}$ のVノッチ加エし, また中心部幅 $5 \mathrm{~mm}$ 厚さ $4 \mathrm{~mm}$ に 切削加工を施して引張り試験片を作製した。これらを $\mathrm{Ar}$ 気流中で $850^{\circ} \mathrm{C}, 25 \mathrm{~min}$ 保持後油中へ焼入机し, 脱油後 $650^{\circ} \mathrm{C}, 60 \mathrm{~min}$ 焼㞍し処理した.

衝撃強さは $30 \mathrm{~kg} \cdot \mathrm{m}$ 衝撃試験機により,引張り強さは インストロンを用い, 硬さはロックウェルCスケールに て測定した。なお，強さ試験は室温で実施した。試料の密 度は水中置換法により, また組織を光学顕微鏡にて観察 し，顕微鏡写真よりマイクロメーターによって $2 \times 2 \mathrm{~mm}$ の範囲の空隙 (Cr の酸化物む含む)の Mean Free Path (M. F. P.) ならびに鍛造方向と平行面のオーステナイト 結晶粒度（JIS 規格：G 0551）を測定した。試料の酸素
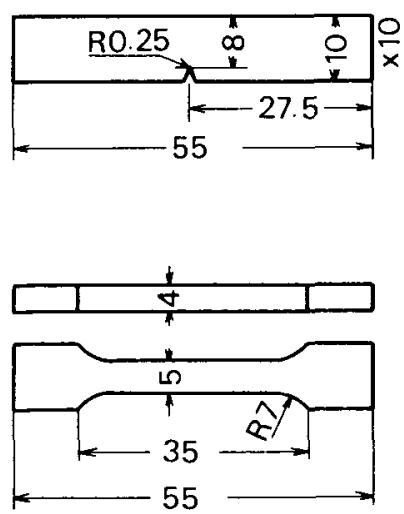

Unit $\mathrm{mm}$

Fig. 1 Dimensions of tensile and impact test specimens.
量は化学分析に上り測定し，成分元素の濃度を EPMA により調べ, 更に強さ試験後の破面をSEM にて観察し た.とれらと強さとの関係を検討した。

\section{III 実 験 結 果}

\section{III -1 鍛造条件之密度との関係}

鈠造加熱温度之加圧力を变えた場合の密度を Fig. 2 に 示す.一般の鉄系と同様に加圧力が高くなるにつれて密 度は上昇し, $1100^{\circ} \mathrm{C}, 9 \mathrm{t} / \mathrm{cm}^{2}$ 以上で約 $7.83 \mathrm{~g} / \mathrm{cm}^{3}$ 亿飽 和したＦP の場合すむちろん傾向は同じであるが, 両 者の密度を比べると加熱温度 $900^{\circ} \mathrm{C}$ の場合, 同一加圧下 で $\mathrm{CP}$ が $\mathrm{FP} よ り$ 約 $0.1 \mathrm{~g} / \mathrm{cm}^{3}$ 程高い， $1100^{\circ} \mathrm{C}$ では密 度の差は小さく加圧力 $9 \mathrm{t} / \mathrm{cm}^{2}$ 以上でほ等しい。乙れ ら用いたプレホームは $1250^{\circ} \mathrm{C}, 60 \mathrm{~min}$ 一次焼結したも ので密度は $\mathrm{CP}$ が $7.1 \mathrm{~g} / \mathrm{cm}^{3}, \mathrm{FP}$ で $6.9 \mathrm{~g} / \mathrm{cm}^{3}$ であり $\mathrm{CP}$ の方が高い，Fe 系7ではプレホーム密度が高い之同 一加圧力での焼結鍛造密度も高くなるが, 成形圧力を調 整し， CP と FP のプレホーム密度を同等にしてあ，た とえば $900^{\circ} \mathrm{C}$ の場合, 焼結鍜造密度は FP の方が低い, 理由はプレホームの空隍径が小さいほど高い降伏応力が 必要8で, CP 空陌は大きく FP では小さい.

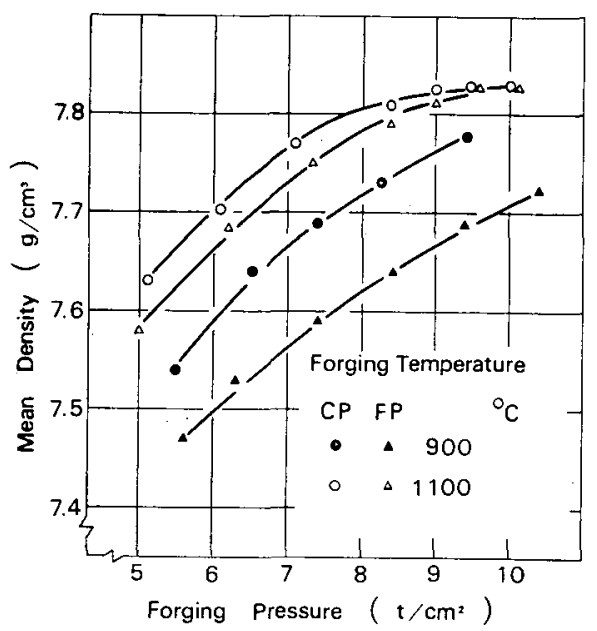

Fig. 2 Relation between forging pressure and mean density on each forging temperature. 


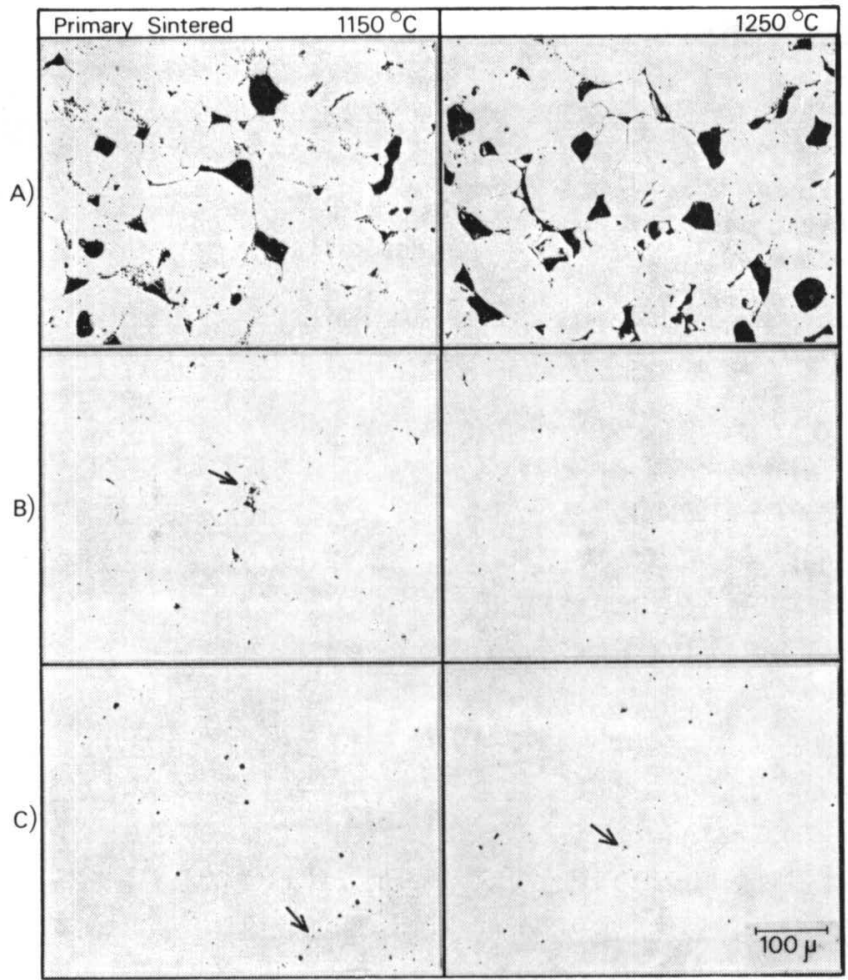

Photo. 1 Distribution of residual pores in preform and sinter-forged $1 \% \mathrm{Cr}$ steel (CP). A) Preform. B) As forged, $1100^{\circ} \mathrm{C}, 9.5 \mathrm{t} / \mathrm{cm}^{2}$. C) After secondary sintering: $1250^{\circ} \mathrm{C}, 30 \mathrm{~min} . \quad(\leftarrow$ : Original porous surface layer of particle.)

\section{III -2 組織および酸素量}

Photo. 1 は CPのプレホーム, 鍛造後および二次焼結 後の試料断面写真を示す. 写真にみるようにプレホーム には原料粉粒子間の粗大な空隙と粒子表層多孔質部 ${ }^{11}$ に 相当する微細な空隙がある，粗大な空隙は一次燒結温度 が高いとわずかに球状化傾向にあるが, 形態に大きな変 化はない。一方微細な空隙部には非金属介在物が含まれ， これらは一次焼結温度が高いほど数少なくなった．鍛造 後の試料にも空隙と非金属介在物は観察され, 一部が Photo. 1 の矢印で示すような集団を形成している．との 集団は原料粉粒子の多孔質表層が残存したもので一次焼 結温度が高い場合ほよ゙少ない. 二次焼結後の試料にも空 隙および非金属介在物はみられ，乙れら試料中の分布は 鍛造したままの状態を保つ。しかし，形状は鍛造したま までは角張ったものが多く，二次佬結を高温長時間おこ なうと球形となる (Photo. 4参照). FP の場合も空隙 および非金属介在物は残存し，二次焼結によって球状化 するが，原料粉が微粉で粒子表層に多孔質がないため, CP にみられるような空隙集団はほとんどなく，空隙お よび非金属介在物は試料中にほぼ均一に分散している。 なお，試料中の空隙および非金属介在物は EPMA によ って判別するととができ，その一例を Photo. 2 に示す.
非金属介在物の多くは $\mathrm{Cr}$ の酸化物であった。

次に成分元素の濃度を EPMA 線分析で調べた. Fig. 3 は鍛造後の CP 試料である. 原料粉粒子内の $\mathrm{Cr}$ は約 $1 \%$ あるが, 粒子境界部には $\mathrm{Cr}$ の酸化物があり, そ の近傍の $\mathrm{Cr}$ む $23 \%$ と高い. 二次燒結後屯酸化物は 残存するが，その近傍の $\mathrm{Cr}$ は粒子内に拡散し， $1150^{\circ} \mathrm{C}$ 以上では $\mathrm{Cr} \leqq 1.2 \%$ となる． FP の場合，このような傾 向はない.

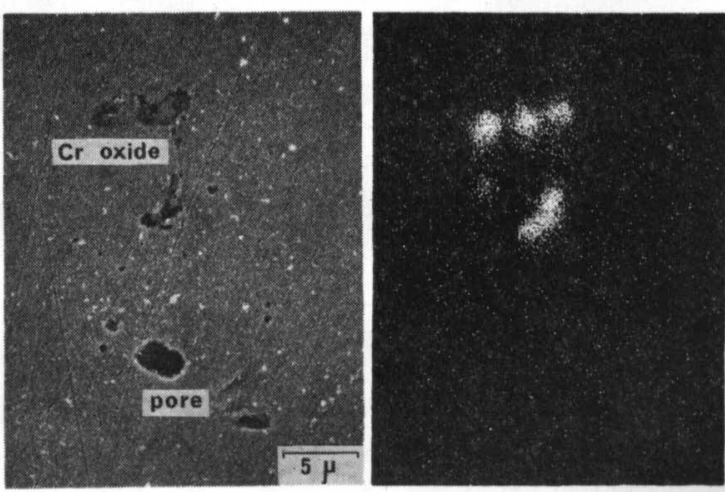

Photo. 2 Scanning electron micrograph and $\mathrm{Cr} \mathrm{K} \alpha$ X-ray image of cross section of sinter-forged $1 \% \mathrm{Cr}$ steel. (Secondary sintering condition: $1250^{\circ} \mathrm{C}$, 30 min.) 


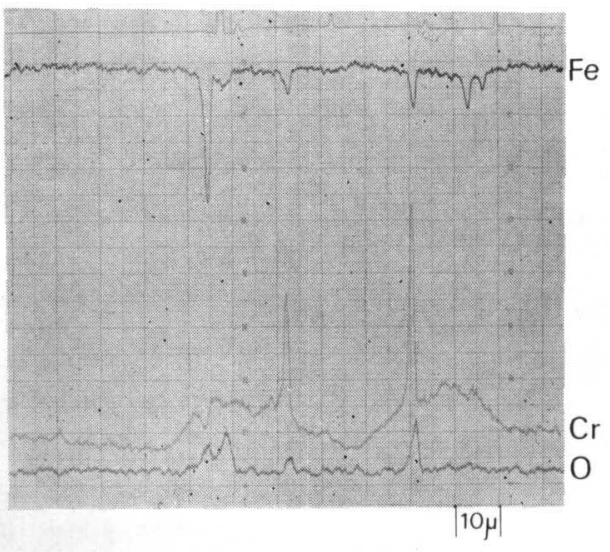

Fig. 3 Line analysis of sinter-forged $1 \% \mathrm{Cr}$ steel (as forged).

これら焼結鍛造後の試料はどれあフェライトとパーラ イトの混合組織を示す。また結晶粒度はどの場合も混粒 で, JIS 規格による粒度番号（平均）は焼ならし試料か 7 , 二次燒結後では $6.5 \sim 7$ の範囲である.

ところでプレホームの酸素量は Fig. 4 亿みられるよう に一次燒結温度によって異なる。ち万温度が高いほ ど酸素量は低く, $1250^{\circ} \mathrm{C}$ 以上で $50 \sim 60 \mathrm{ppm}(\mathrm{CP})$ となる. この酸素量は鉎造後も変らず，また二次焼結によってあ 数 ppm 低下するに過ぎない，たとえば保持時間 $60 \mathrm{~min}$ で一次燒結温度 $1150^{\circ} \mathrm{C}$ ならびに $1250^{\circ} \mathrm{C}$ の場合，鍛造

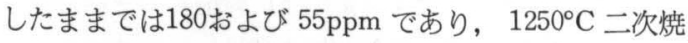
結後はそれぞれ 170 と $48 \mathrm{ppm}$ である. との場合, 試料表 面より $2 \mathrm{~mm}$ 以内の部分を分析した平均值である. 鍛造 は大気中でおこなうため, 鍛造したままでは表面に酸化 スケールが生成している，鍛造後，試料表面を研摩し， $1200^{\circ} \mathrm{C}$ 以上で二次焼結すると表面より $2 \mathrm{~mm}$ までの部

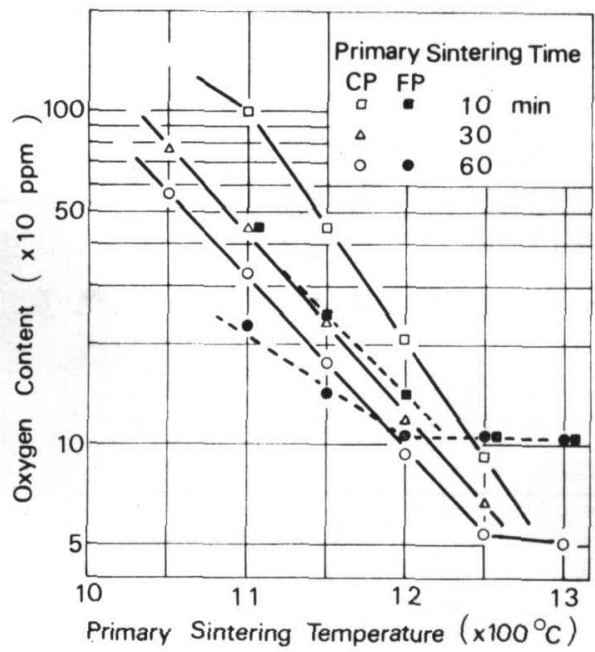

Fig. 4 Effect of primary sintering temperature on oxygen content of preforms.

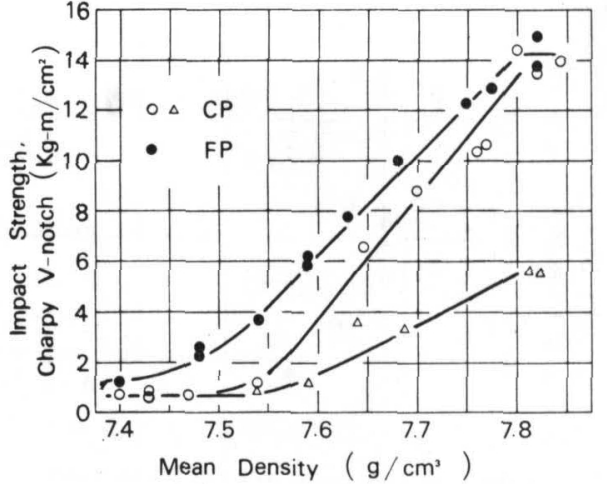

Fig. 5 Relation between density and impact strength of sinter-forged $1 \% \mathrm{Cr}$ steel. (Primary sintering temperature: $1250^{\circ} \mathrm{C} \triangle 1150^{\circ} \mathrm{C}$ ). (Secondary sintering temperature: $1250^{\circ} \mathrm{C}$ ).

分の酸素量は $100 \mathrm{ppm}$ 以下となる.

III-3 衝 撃 值

Fig. 5 亿密度之衝撃值との関係を示す. 図中衝撃値は 低密度側では $1 \mathrm{~kg}-\mathrm{m} / \mathrm{cm}^{2}$ 以下であるが, 密度 $7.5 \mathrm{~g} / \mathrm{cm}^{3}$ 以上になると急激に上昇し, $7.8 \mathrm{~g} / \mathrm{cm}^{3}$ 以上で最高值と なり飽和した．FP の衝撃值は低密度側で $\mathrm{CP}$ 上り高い。

次に密度 $7.80 \sim 7.83 \mathrm{~g} / \mathrm{cm}^{3}$ に鍛造した $\mathrm{CP}$ の衝撃值 に及ぼす一次焼結条件の影響を Fig. 6 亿示す。 なお二次 焼結は $1250^{\circ} \mathrm{C}, 30 \mathrm{~min}$ に一定した. 衝撃值は温度が高く 保持時間が長いほど上昇し, 保持時間 $60 \mathrm{~min}$ の場合, 温度 $1200^{\circ} \mathrm{C}$ 以上で飽和した. FP の衝撃值に及ぼす一 次燒結条件の影響は $\mathrm{CP}$ ほど顕著でなく, 各温度におい て保持時間 $10 \mathrm{~min}$ の場合之 $1150^{\circ} \mathrm{C}$ 以下の之きに 1 4 $\mathrm{kg}-\mathrm{m} / \mathrm{cm}^{2}$ 程低い值を示したが，それ以外は $13.5 \sim 15$ $\mathrm{kg}-\mathrm{m} / \mathrm{cm}^{2}$ の範囲にある.

ところで前記のように一次燒結条件によって試料の酸 素量は異なるが, 衝撃値と酸素量との関係は Fig. 7 の

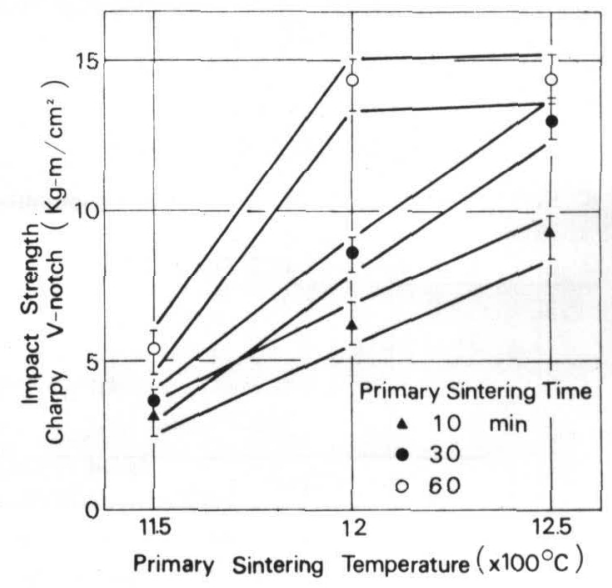

Fig. 6 Effect of primary sintering temperature on impact strength of sinter-forged $1 \% \mathrm{Cr}$ steel $(\mathrm{CP})$. (Secondary sintering condition: $1250^{\circ} \mathrm{C}, 30 \mathrm{~min}$ ) 


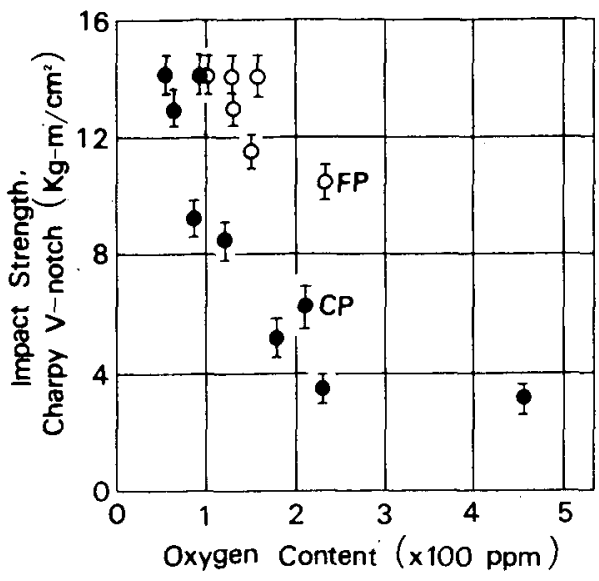

Fig. 7 Relation between oxygen content and impact strength of sinter-forged $1 \% \mathrm{Cr}$ steel. (Secondary sintering condition: $1250^{\circ} \mathrm{C}, 30 \mathrm{~min}$.)

うになる.図にみるように同一試料については酸素量が 高いと衝整值も概して低いか， $\mathrm{CP}$ とFP を比較すると， 酸素量が同等でむ衝撃值は大幅に異なる。

二次焼結を省けば（焼ならし）衝撃值は低い。たとえ ば $1250^{\circ} \mathrm{C}, 60 \mathrm{~min}$ 一次焼結し，鉎造後烧ならした場合 の衝撃値は 8〜 $9 \mathrm{~kg}-\mathrm{m} / \mathrm{cm}^{2}(\mathrm{CP})$. それより低温または短 時間焼結では更に低い値を示す。二次烇結の影響は Fig.

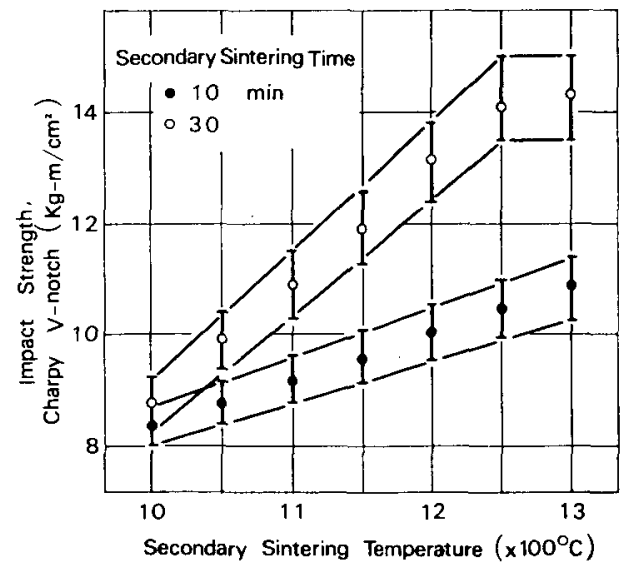

Fig. 8 Effect of secondary sintering temperature on impact strength of sinter-forged $1 \% \mathrm{Cr}$ steel (CP). (Primary sintering condition: $1250^{\circ} \mathrm{C}, 60 \mathrm{~min}$.)
8 にみるように大きい，すなわち一次焼結が $1250^{\circ} \mathrm{C}, 60$ $\min$ の場合, 二次焼結が $1000^{\circ} \mathrm{C}$ 程度では焼ならし漹料 之ほぼ同じ衝軳值であるが，高温，長時間保持になるほ ど上昇し，保持時間 $30 \mathrm{~min}$ の場合, $1250^{\circ} \mathrm{C}$ 以上で 13.5 $\sim 15 \mathrm{~kg} \cdot \mathrm{m} / \mathrm{cm}^{2}$ の範囲に飽和する，乙の値は狫ならし試 料の約 1.7 倍である.FP の場合もこのような傾向は全 く同様である.

一方衝撃值の場合と異なり引張り強さには一次, 二次 焼結の温度依存性はほとんどみられない，Table 2 に引 張り試験結果と硬さを示す．伸びは二次焼結条件によ。 て若干差があり，温度が高いとわずかに高くなる．硬さ はどれあほぼ同じであった。

$$
\mathrm{IV} \text { 考察 }
$$

IV-1 空隙の Mean Free Path と衝撃值との関係

$\mathrm{CP}$ の場合, 空腺 $(\mathrm{Cr}$ の酸化物も含む) は一次燒結条 件によってその分布が異なる (Photo. 1 参照)。そとで 空隙の分布と衝撃值との関係を検討した.

顕微鏡写真より測定した空隙（こてでは酸化物も含め た総称である)の M.F.P.をパラメータとすると, CP の分布状態は Fig. 9 のようになる. M.F.P. 約 $2 \mu$ と $10 \mu$ にそれぞれピークを持つ分布を示し，特に注目すべきは 一次燒結条件によって $2 \mu$ 㑡のピークが変動することで ある. この $2 \mu$ 側のピークは Photo. 1 の矢印で示すよう な空隙集団に属し，図中 $7 \mu$ 以下に対応するとみられる. 破堎に怙いててのような部分はき裂発生の堆積場であり， 低い負荷応力でき裂は容易に成長しよう。 M.F.P. $<7 \mu$ の分率之衝撃値亡の関係は Fig. 10 のようになり，相関 性は有意である.すなわち CP の衝撃特性は空腙の分布 状態にも関係すると考えられる。

FP では上記の上うな関係は明らかでない，理由は， FP の原料粉は微粉で粒子表層が多孔質でなく，焼結鍛 造復の空腺はほほ均一に分布し，一次焼結条件が異なっ ていてあ分布に大きな差がないからである。したがって 衝撃值に及代す空隍分布の影響は小さく，また，同一酸 素量での衝撃值を $\mathrm{CP}$ と比較した場合など, 分布が均一 でない CPの方が低くなったと考えられる (Fig. 7 参照).

Table 2 Tensile properties and hardness of sinter-forged $1 \% \mathrm{Cr}$ steel (Primary sintering condition: $1250^{\circ} \mathrm{C}, 60 \mathrm{~min}$, Secondary sintering condition: $1250^{\circ} \mathrm{C}, 30 \mathrm{~min}$ ).

\begin{tabular}{|c|c|c|c|c|c|}
\hline & Treat & $\begin{array}{c}\text { Tensile strength } \\
\mathrm{kg} / \mathrm{mm}^{2}\end{array}$ & $\begin{array}{l}\text { Yield strength } \\
\mathrm{kg} / \mathrm{mm}^{2}\end{array}$ & $\begin{array}{c}\text { Elongation } \\
96\end{array}$ & $\begin{array}{c}\text { Hardness } \\
H_{R} C\end{array}$ \\
\hline \multirow{2}{*}{$\mathrm{CP}$} & Secondary sintered & $84 \sim 85$ & $73 \sim 76$ & $22 \sim 26$ & $21 \sim 26$ \\
\hline & Normalized & $" \prime$ & $73 \sim 74$ & $20 \sim 24$ & $" \prime$ \\
\hline \multirow{2}{*}{ FP } & Secondary sintered & $"$ & $73 \sim 76$ & $25 \sim 27$ & " \\
\hline & Normalized & $"$ & $73 \sim 74$ & $24 \sim 26$ & $"$ \\
\hline
\end{tabular}




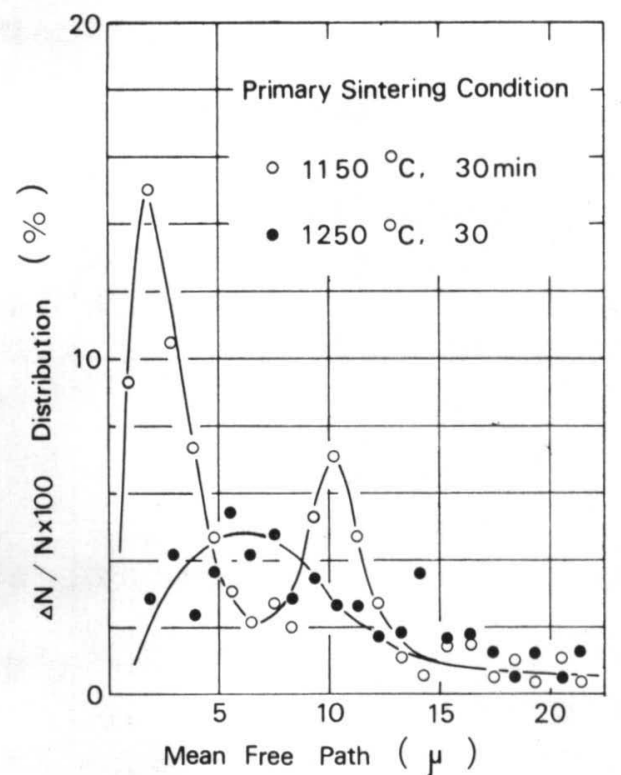

Fig. 9 Mean free path of small pores of sinter-forged $1 \% \mathrm{Cr}$ steel (CP). (Secondary sintering condition: $1250^{\circ} \mathrm{C}, 30 \mathrm{~min}$.)

\section{$\mathrm{N}-2$ 空隙形状と衝撃值との関係}

前述の上うに一次燒結条件を一定とし, 鍛造後, 二次 燒結すると，しないものより更に高い衝撃值を示す．と の二次焼結では酸素, $\mathrm{Cr}$ の酸化物, 空隙などの量, 分 布とあに変動は小さく, 結晶粒度む6.5 7 (平均) の範 囲に留まる．そこで破面を観察し，その原因について検

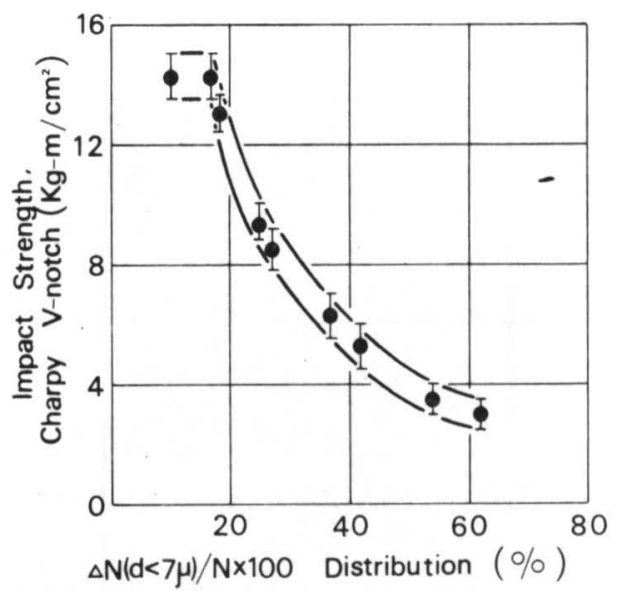

Fig. 10 Effect of mean free path of small pores $(\mathrm{d}<7 \mu)$ on impact strength of sinter-forged $1 \% \mathrm{Cr}$ steel (CP). (Secondary sintering condition: $1250^{\circ} \mathrm{C}, 30$ $\min$.)

討を加えた.

焼ならし試料 $\left\{\right.$ a ): 衝撃値 $\left.8 \mathrm{~kg}-\mathrm{m} / \mathrm{cm}^{2}\right\}$ と $1250^{\circ} \mathrm{C}$ 二次焼結した試料 $\{\mathrm{b})$ : 衝撃値 $\left.14 \mathrm{~kg}-\mathrm{m} / \mathrm{cm}^{2}\right\}$ の破面 写真を Photo. 3 亿示す (CP). 両者とも酸素量は 50 60 ppm である. 破面を巨視的にみると， a )では原料粉粒 子の概形が認められ，更に粒子間ネックにき裂が生じて おり破壊かての部分を選択的に伝播したととを示す.一 方 b )では原料粉粒子の概形は認めがたい，微視的には a )は局部的（ネック部）に，b）は全面にわたり非金属
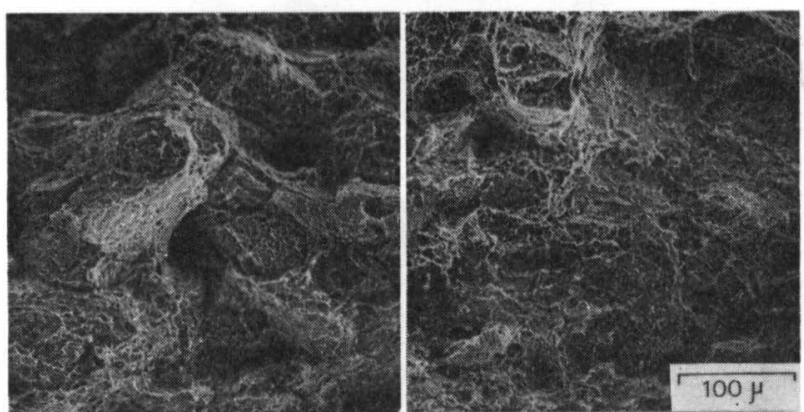

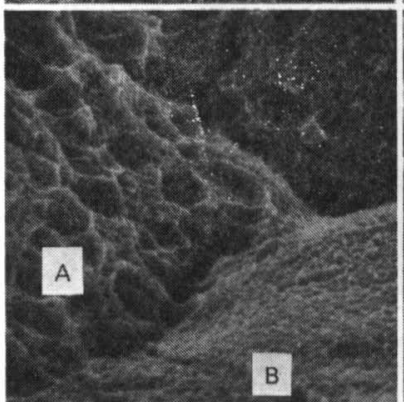

a)

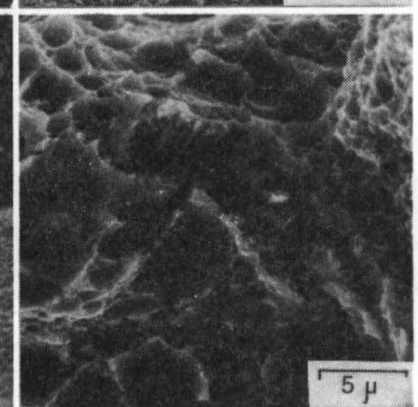

b)

Photo. 3 SEM of fracture surface of sinter-forged $1 \% \mathrm{Cr}$ steel. a) Normalized, impact: $8 \mathrm{~kg}$ $\mathrm{m} / \mathrm{cm}^{2}$ b) Secondary sintered at $1250^{\circ} \mathrm{C}$ for $30 \mathrm{~min}$, Impact: $14 \mathrm{~kg}-\mathrm{m} / \mathrm{cm}^{2}$. (A: Neck of particles, B: Portion of collapsed pore.) 


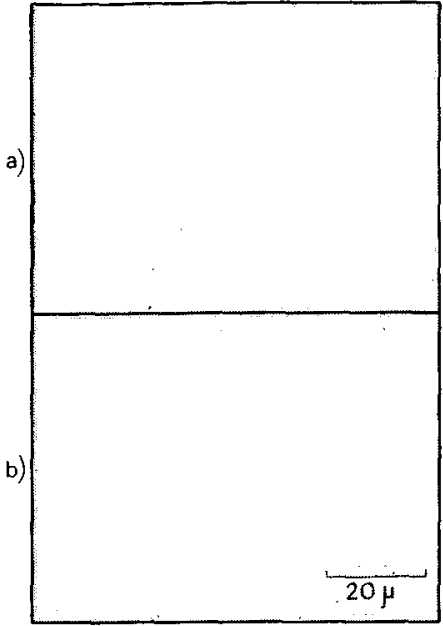

Photo. 4 Change of small pores on secondary sintering condition of sinter-forged $1 \% \mathrm{Cr}$ steel. a) Normalized, b) Secondary sintered at $1250^{\circ} \mathrm{C}$ for $30 \mathrm{~min}$.

介在物および空陌を核としたデインプル破面を示す。し たがって二次焼結しないa）においてはネック部周辺に デインプルがないととから鍛造によって任着された元空 隙部*が存在し，乙の部分の結合は弱いとみられる. 更 に Photo. 4.a) にみるように原料粉粒子間の粗大空隙が 王着された部分には鋭い角を持った空隙が残存し，その 角の先に結合の弱い空腺圧着部が続いているはずである。 このような材料外力が作用した場合, 非金属介在物な どにき裂が生じ（空隙はき裂であり，また金属結合の弱 い部分は低い真荷応力で容易にき裂となりうる)，き裂 は空隙圧着部方向に低い真荷応力で容易に成長，合体し， 低い伝播エネルギーで破壊にいたると考えられる。一方， 二次佬結した b )では空隙圧着部の金属結合を十分にし, 加空淂は球形 (Photo. 4. b) 参照) となり，き裂の成

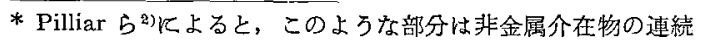
した粒子境界部である. EPMA 分析火よる本詿料の場合， 非金属介在物の見い出せない部分が多く，そのため空腺王着 部とした.
}

長，合体（球形な空陌をき裂が通過する場合などき裂先 端を鈍化する）には高い負荷応力が必要で, 高い伝播エ ネルギーで破壊すると考えられる。FPにおいても同様 なととが言える。

以上のととから焼結鈠造工程において材料の衝撃強さ を高めるためには，残存した空隙および非金属介在物を 球状化することはむちろんであるが, 空隙王着部の金属 結合を十分にするととあ重要で，そのために二次焼結が 必要である。

$$
V \text { 結 言 }
$$

含 $\mathrm{Cr}$ 低合金銅焼結銠造材の機械的性質に及ぼす一次, 二次焼結条件の影響について調べた結果, 次のてとが明 らかとなった。

1）一次燒結は温度が高いほぼ焼結鍛造材の酸素量を 大きく低下させ，かつ CP の場合は空隙の分布 ( $\mathrm{Cr}$ の 酸化物む含めた）を均一とし, 衝撃強さを大いに高める.

2）二次焼結は空除圧着部の金属結合を十分にし，加 つ空陌を球状にして，CP おちよで FP の焼結䤠造材の衝

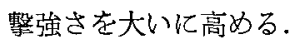

3) 一次, 二次焼結条件は $\mathrm{CP}$ 拈よび FP の引張り強 さならびに硬さにははとんど影響を及ぼさなかった。

\section{文献}

1) 鱞川，武田：粉体および粉末治金， 26 (1979)，289.

2) R.M. Pilliar, W.J. Bratina and J.T. McGrath: Modern Development in Powder Metallurgy, 7 (1973), 51.

3) Per Lindskog and Sven-Erik Grek: Modern Development in Powder Metallurgy, 7 (1973), 285.

4) G. Bockstiegel and C-A. Blände: Powder Metallurgy Int., 8 [4] (1976), 155.

5) G. T. Brown: Metals Technology, 3 [5 6] (1976), 229.

6) G. Bockstiegel and U. Björk: Powder Metallurgy, 17 [33] (1974), 126.

7) H. F. Fischmeister, B. Aren and K. E. Easterling: Powder Metallurgy, 14 [27] (1971), 144.

8) S. M. Kaufman: Int. J. of Powder Metallurgy, 8 [4] (1972), 183. 